Dhaka Univ. J. Biol. Sci. 26(1): 83-90, 2017 (January)

\title{
IDENTIFICATION OF AWAOUS GUAMENSIS AND A. GRAMMEPOMUS BASED ON MORPHOLOGY AND MOLECULAR ANALYSIS
}

\author{
Hawa Jahan*, Mehnus Tabassum and Gulshan Ara Latifa \\ Department of Zoology, University of Dhaka, Dhaka-1000, Bangladesh \\ Key words: Identification, PCR-sequencing, COI gene
}

\begin{abstract}
Work on two freshwater Gobi fish species such as Awaous guamensis and A. grammepomus was carried out on morphometric and meristic study for their morphological identification. Sequence data of mitochondrial cytochrome oxidase subunit I (COI) gene was used for this purpose. Around $620 \mathrm{bp}$ sequences were obtained when universal primers were used. An alignment was performed between the sequences which showed some inter-specific variation. An entropy plot was generated for all the aligned positions which showed that the entropy rarely touches a scale of one, which is a sign of better alignment in the region. This work can be utilized for species identification, phylogenetic analysis, to study molecular diversity and evolution, and most importantly for the conservation of these fauna in near future.
\end{abstract}

\section{Introduction}

Bangladesh enjoys enough advantages being situated at the foot of the Himalayas, influenced by the monsoons and in indated by numerous rivers and streams. The hilly areas with diverse topographic relief and cool waters and remarkable areas of hill streams are predicted to be biodiversity hotspots in Bangladesh. The country has vast fishery potentials within her boundaries and the territorial and economic zones in the sea which offer excellent scope for pisciculture. Thus the nation's total area of waters having fish production potential is very great. The wetlands of Bangladesh are interplay of social, environmental, resource management and developmental concerns ${ }^{(1)}$. All the identifications, description, and taxonomic or systematic literature exist on Bangladesh fishes based on the morphometric characteristics and most of the information is based on the non-vouchered information. Most of the freshwater fishes have not been identified or characterized based on molecular data. The molecular characterization of fishes is urgently needed for their proper identification and conservation. Therefore, the present study is aimed primarily at the molecular identification of Gobi fishes of Bangladesh.

*Author for corresponding: <hawajahan@du.ac.bd>. 
DNA barcoding is a systematic tool for species identification which provides an accurate information and fills the conceptual gap between traditional taxonomy and different fields of molecular systematics. The rationale behind DNA barcoding originates from the accumulation of evidence during the last two decades, as a consequence of an increasing access to genomic data, that the characterization and documentation of biodiversity using phenotypes are currently bridled by several limits inherent to morphological characters. The application of cytochrome c oxidase I (COI) gene for species identification in fish triggered the international initiative for barcoding all fishes $^{(2)}$. The encouraging results have prompted international efforts to standardize screening of species diversity and to accelerate the process of cryptic species identification. Gobiidae is one of the largest families of teleost fishes, with nearly 2000 extant species currently recognized, distributed all over the world, consists of poorly explored freshwater fishes of Bangladesh. In the case of Perciformes fishes, it is difficult to differentiate the species because of the similarity in external morphology. The current study highlighted the use of COI gene as a genetic marker for the identification of morphologically similar species. This study will be useful for Awaous sp. identification, and most importantly for the conservation of these species in near future.

\section{Materials and Methods}

Two specimens of two freshwater Gobi fish species (Fig. 1) were collected from different regions of Bangladesh. Tissues from these samples were preserved in $95 \%$ ethanol for molecular study and stored at $-20^{\circ} \mathrm{C}$. Apart from this, the whole samples were also preserved in formalin as voucher specimen for further study.

The isolation of genomic DNA from the fish samples was carried out by CTAB $\operatorname{method}^{(3)}$. For this purpose, the muscle tissues were homogenized in $500 \mu$ l extraction buffer containing $100 \mathrm{mM} \mathrm{NaCl}, 50 \mathrm{mM}$ Tris- $\mathrm{HCl}$ (pH 8.0), and $10 \mathrm{mM}$ EDTA, followed by digestion in $10 \mu \mathrm{l}$ of proteinase $\mathrm{K}$ to a final concentration of $0.4 \mathrm{mg} / \mathrm{ml}$ at $55^{\circ} \mathrm{C}$ for one day. By the phenol: chloroform extraction method, DNA was purified. Ethanol was precipitated with $0.1 \mathrm{vol}$ of $3 \mathrm{M}$ sodium acetate and $2 \mathrm{vol}$ of absolute ethanol at $-20^{\circ} \mathrm{C}$ for one day. The DNA pellets were washed with $70 \%$ ethanol and allowed to dry at $37^{\circ} \mathrm{C}$ for 6 to $10 \mathrm{~min}$. Thus the prepared DNA was dissolved in $100 \mu \mathrm{l}$ TE buffer and stored at $-20^{\circ} \mathrm{C}$ until used. Finally, the extracted DNAs were electrophoresed on a $1.0 \%$ lowmelting-temperature agarose gel and stained with ethidium bromide for band characterization using ultraviolet transillumination ${ }^{(4)}$.

Extracted DNAs of the samples were amplified using PCR. DNA amplification of MT-COI gene was carried out in Thermo Cycler by using the modified universal forward(5) and reverse( ${ }^{(6)}$ primers (Table 1) of freshwater fish. Around $650 \mathrm{bp}$ of the COI gene was amplified by using these primers. A mixture of $25 \mu \mathrm{l}$ solution containing master mix (1x Invitrogen Platinum Taq Buffer, $0.25 \mathrm{mM}$ each of deoxynucleotide 
triphosphate (dNTPs), $2.0 \mathrm{mM} \mathrm{MgCl}$, and 0.5 units of Taq DNA polymerase), $10 \mathrm{pmol}$ of each primer, $100 \mathrm{ng}$ of genomic DNA). The reactions were conducted using a Thermal Cycler under the following conditions: an initial denaturation at $95^{\circ} \mathrm{C}$ for $6 \mathrm{~min} ; 30$ cycles of $94^{\circ} \mathrm{C}$ for $30 \mathrm{~s}, 55^{\circ} \mathrm{C}$ for $30 \mathrm{~s}$ and $72^{\circ} \mathrm{C}$ for $40 \mathrm{~s}$; and concluded with a final elongation step of $72^{\circ} \mathrm{C}$ for $10 \mathrm{~min}$ followed by a hold at $4^{\circ} \mathrm{C}$. For PCR, a negative control containing double distilled water instead of DNA was included. Electrophoresis of amplified DNA products was conducted with $1.0 \%$ agarose gel in $1 \mathrm{X}$ electrophoresis buffer and visualized under ultraviolet (UV) light after staining with $5 \mu$ l ethidium bromide. A 100 bp DNA ladder (Bioron, Germany) was used to estimate sizes of the products.
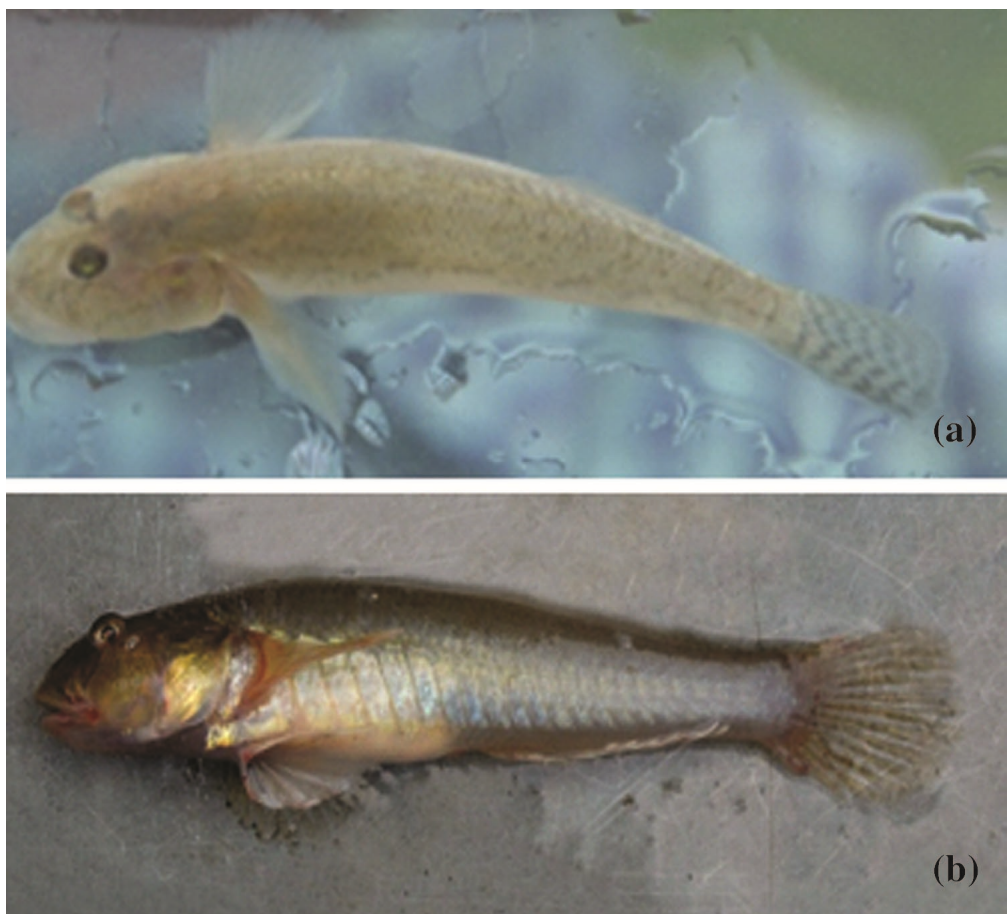

Fig. 1. Gobi fishes (a) Awaous guamensis (Valenciennes, 1837) (Scribbled Goby) and (b) Awaous grammepomus (Bleeker, 1849) (Streaked River Goby).

Table 1. Primers used in this study.

\begin{tabular}{lcc}
\hline Primer name & Sequence $(5 \rightarrow 3)$ & Reference \\
\hline CO1 $\mathrm{F}$ & GGTCAACAAATCATAAAGATATTGG & Folmer et al. 1994(5) \\
CO1 $\mathrm{R}$ & TAGACTTCTGGGTGGCCAAAGAATCA & Ward et al. 2005(6) \\
\hline
\end{tabular}


PCR products were purified using the PCR Cleanup kit. After purification they were sent to Centre for Advanced Research in Science (CARS), University of Dhaka for sequencing. The sequencing was carried out by Sanger Sequencing method.

To determine the highest homolog, sequences were identified by using BLAST search at NCBI. SEQUENCHER(7) and BIOEDIT(8) were used for sequence analysis. Sequences were aligned using CLUSTAL $W^{(9)}$. This alignment shows both similarity and dissimilarity between the sequences. An Entropy Hx plot was drawn by BioEdit software to show variability between the sequences.

\section{Results and Discussion}

Two species of Gobi fish were identified morphologically by using taxonomic keys ${ }^{(10)}$. A morphometric and meristic study was performed comprised of average body, head measurement and average number of fin/spines measurements (Table 2). However, sometimes morphological study is not enough for identification. Species identification by morphological features is sometime ineffective and misleading, because, larval stages of some species groups often cannot be assigned to the correct species ${ }^{(11)}$. Besides, the morphological identification is more complicated when the species are damaged due to rough handling, and there may have chances for fish fraud ${ }^{(12)}$.

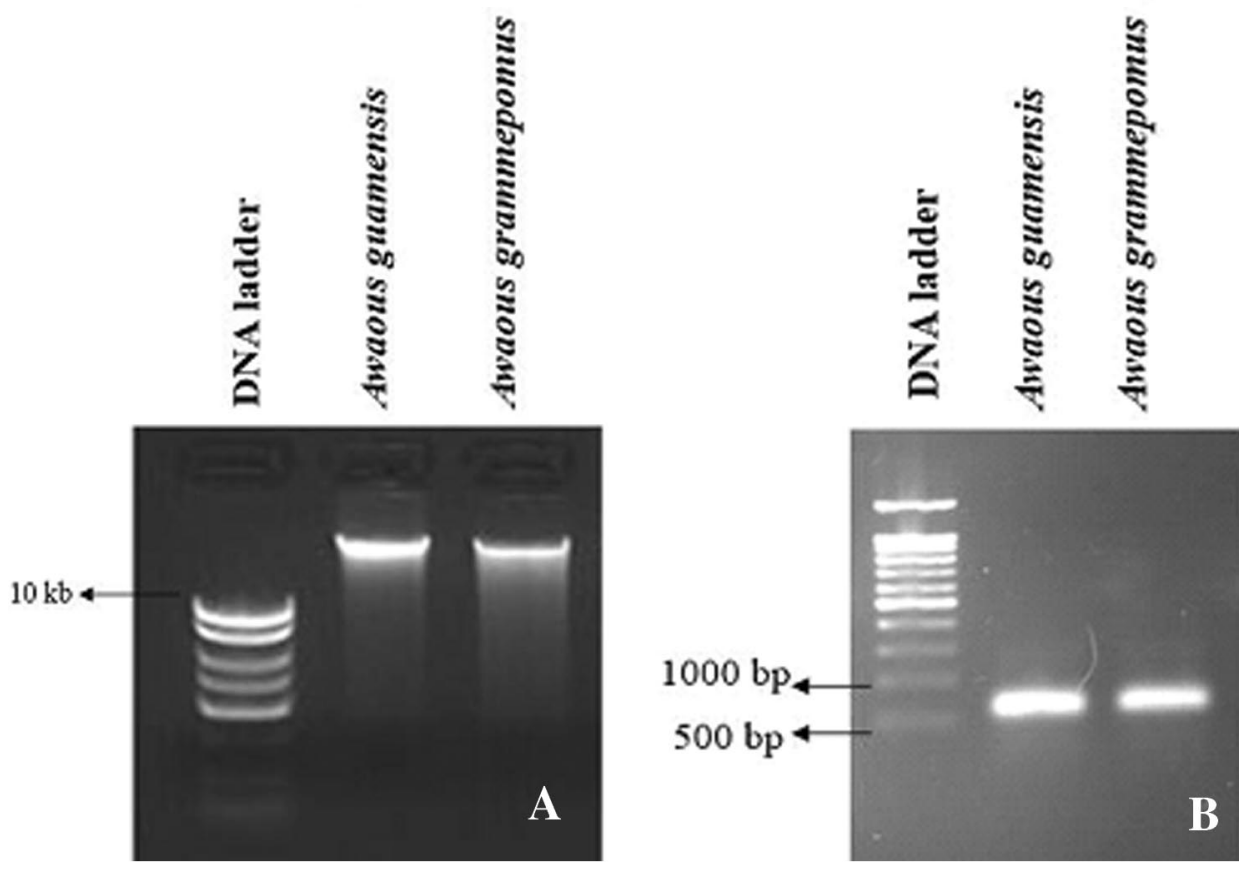

Fig. 2. Images of agarose gel electrophoresis for extracted DNA of A. guamensis and A. grammepomus (A), COI primer based PCR (B). 
Total genomic DNA of both the species were isolated (A of Fig. 2) and were amplified successfully through polymerase chain reaction (PCR). One per cent AGE showed PCR products of COI gene of about $650 \mathrm{bp}$ for A. guamensis and A. grammepomus (B of Fig. 2). In the present study, for both the species, universal primers for partial COI gene showed satisfactory results whereas in some cases universal primers are not enough for species identification and species-specific $\mathrm{CO} 1$ primer is required as a study showed that the success of the amphibian species-specific primers (78\%) had an increase of $46 \%$ over the universal primers(13).

Table 2. Morphological characteristics of Gobi fishes.

\begin{tabular}{|c|c|c|c|c|c|c|c|c|c|c|}
\hline \multirow[b]{2}{*}{ Species } & \multicolumn{5}{|c|}{ Body measurements (average) } & \multicolumn{5}{|c|}{ Head measurements (average) } \\
\hline & $\begin{array}{l}\mathrm{TL} \\
(\mathrm{cm})\end{array}$ & $\begin{array}{l}\mathrm{SL} \\
(\mathrm{cm})\end{array}$ & $\begin{array}{l}\text { PDL } \\
(\mathrm{cm})\end{array}$ & $\begin{array}{l}\mathrm{BD} \\
(\mathrm{cm})\end{array}$ & $\begin{array}{l}\text { PD } \\
(\mathrm{cm})\end{array}$ & $\begin{array}{l}\mathrm{HL} \\
(\mathrm{cm})\end{array}$ & $\begin{array}{l}\text { ED } \\
(\mathrm{mm})\end{array}$ & $\begin{array}{l}\text { Pr.OL } \\
(\mathrm{mm})\end{array}$ & $\begin{array}{l}\text { Po.OL } \\
(\mathrm{mm})\end{array}$ & $\begin{array}{l}\text { IOL } \\
(\mathrm{mm})\end{array}$ \\
\hline $\begin{array}{l}\text { Awaous } \\
\text { guamensis }\end{array}$ & 12.5 & 8.7 & 1.4 & 1.9 & 1.2 & 3.2 & 0.4 & 8.7 & 1.4 & 0.5 \\
\hline $\begin{array}{l}\text { Awaous } \\
\text { grammepomus }\end{array}$ & 11 & 8.2 & 1.3 & 1.5 & 1.2 & 3.0 & 0.3 & 7.8 & 1.4 & 0.4 \\
\hline
\end{tabular}

Table contd. (right side).

\begin{tabular}{|c|c|c|c|c|c|c|c|c|c|c|}
\hline \multicolumn{5}{|c|}{ Average fin base length (mm) } & \multicolumn{6}{|c|}{ Average number of fin rays/spines } \\
\hline \multicolumn{2}{|c|}{ DFB } & \multirow[t]{2}{*}{ P1FB } & \multirow[t]{2}{*}{$\mathrm{P} 2 \mathrm{FB}$} & \multirow[t]{2}{*}{ AFB } & \multicolumn{3}{|c|}{ DFR } & \multirow[t]{2}{*}{ P1FR } & \multirow[t]{2}{*}{ AFR } & \multirow[t]{2}{*}{ CFR } \\
\hline 1st & 2nd & & & & D1 FS & D2FS & D2FR & & & \\
\hline 0.3 & 3.3 & 0.7 & 2.4 & 1.4 & 7 & 1 & 10 & 16 & 10 & 13 \\
\hline 0.3 & 3.2 & 0.6 & 2.2 & 1.4 & 6 & 1 & 10 & 15 & 10 & 13 \\
\hline
\end{tabular}

For the above mentioned CO1 primer, both the samples were sequenced in both directions, with an average DNA quality of $98 \%$ (after trimming) and an average sequence length of $620 \mathrm{bp}$. Values of overall sequence quality were calculated by the Sequencher 4.10.1 program.

Blast identified both the species accurately to species level and showed 99\% of similarity to the existing sequences of particular species in the NCBI Genbank database. A BLAST pairwise circular tree was drawn (Fig. 3) by fast minimum evolution tree method which showed the existence of same ancestry for both the species as taxonomy refers. 


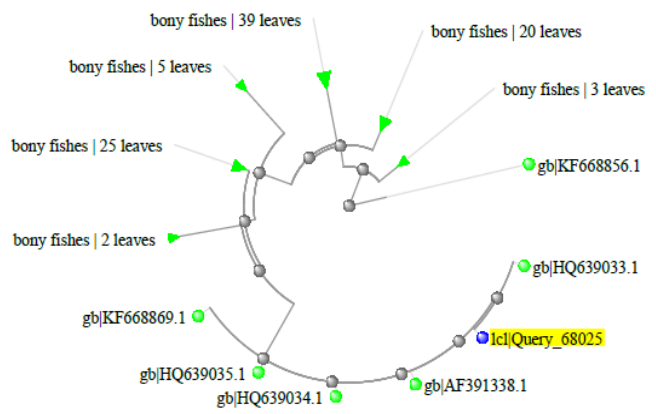

(A)

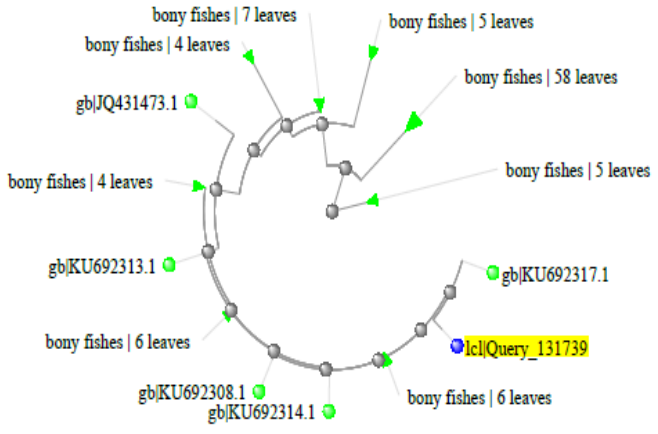

(B)

Fig. 3. BLAST search result showing BLAST pairwise tree (Fast minimum evolution tree method) for A. guamensis (A) and A. grammepomus (B).

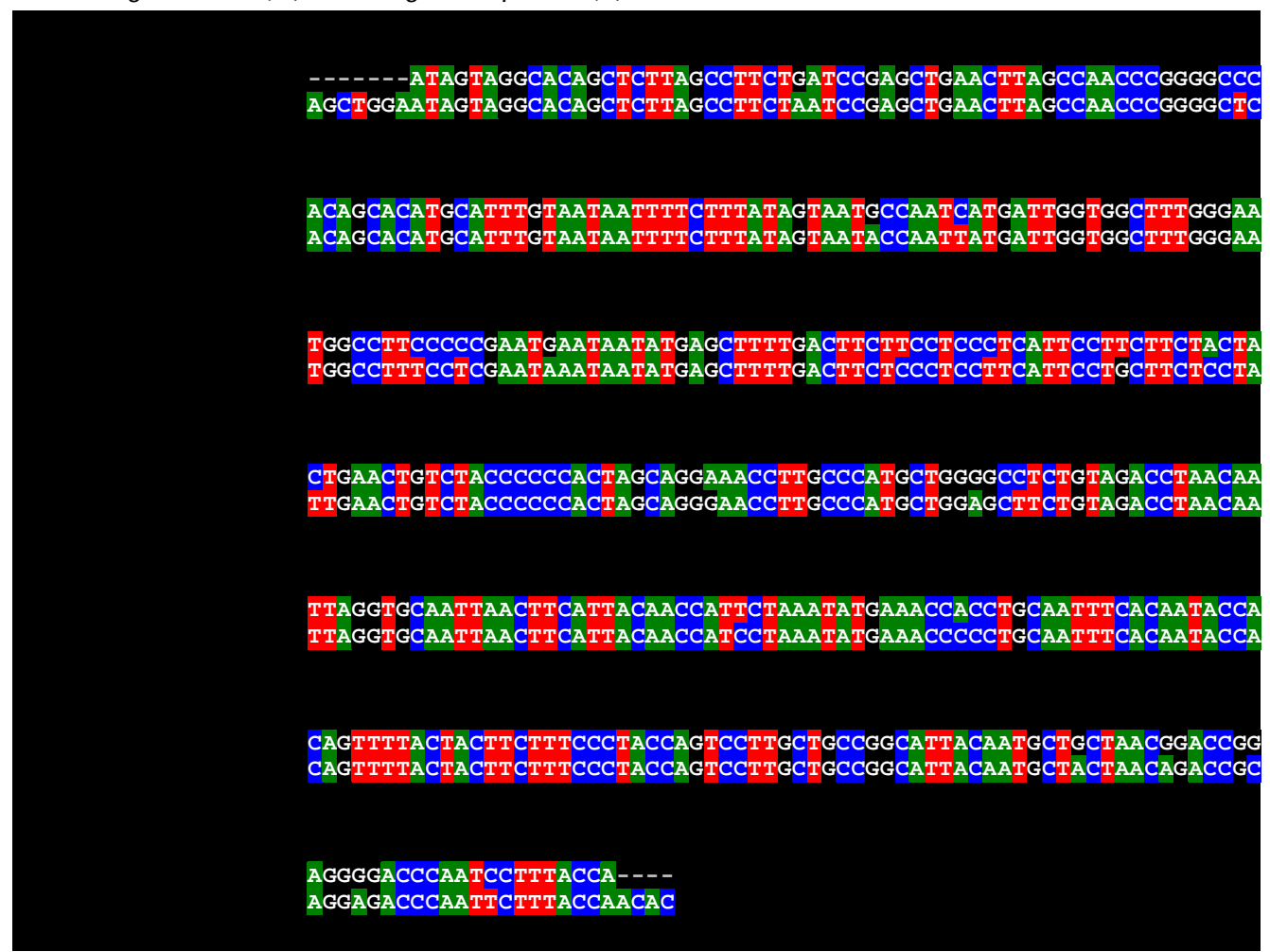

Fig. 4. Interspecific alignment pattern between A. guamensis and A. grammepomus.

Interspecific comparison can classically be defined as the comparison of gene sequences between different organisms of the same genus to identify the regions of similarities and dissimilarities ${ }^{(14)}$. In this study, the interspecific variation of partial 
regions of mitochondrial COI gene between A. guamensis and A. grammepomus from Bangladesh was studied. Sequences were aligned using Bioedit and 19 polymorphic sites were observed (Fig. 4) within a total of 614 base pairs. The percentage of polymorphic site is $3 \%$ which shows the genetic diversity between two closely related species. Genetic diversity in the wild is crucial for the culture of farmed populations.

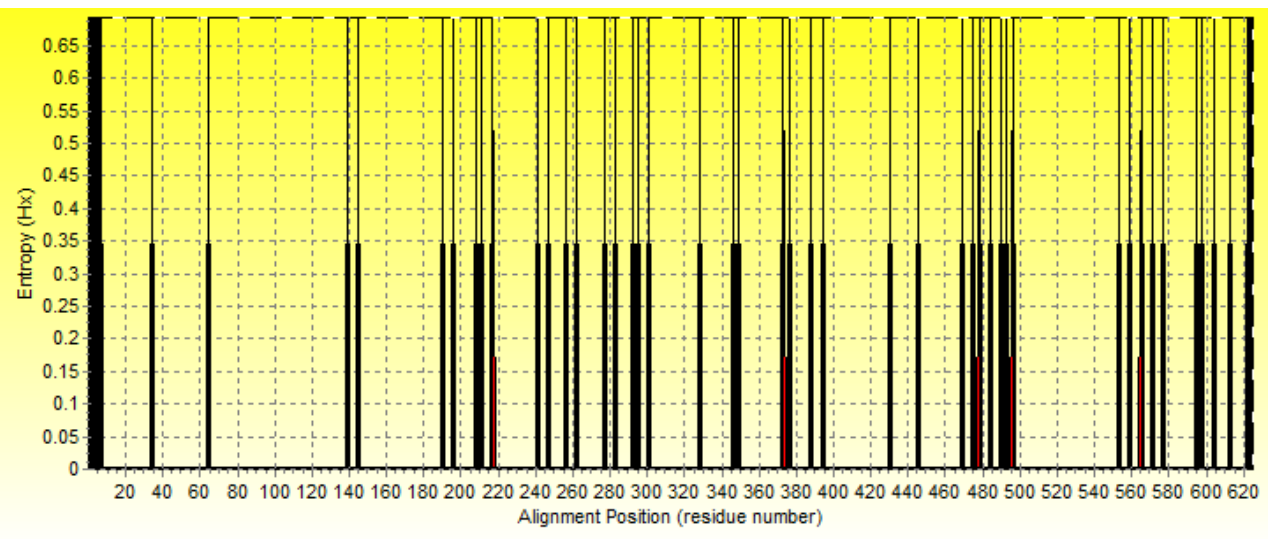

Fig. 5. Entropy Hx plot.

An entropy plot can give an idea of the amount of variability through a column in an alignment ${ }^{(15)}$. In this study, an entropy plot (Fig. 5) was presented for all the aligned positions which shows that the entropy barely touches a scale of one and in most of the positions it is below 0.35 , which is a sign of better alignment in the region.

\section{Conclusion}

Gobies are cryptic bottom-dwelling carnivores and poorly explored in the freshwater of Bangladesh. Despite the spectacular variation and commercial importance of Gobi fishes, morphological and molecular data of this group from Bangladesh is still insufficient. These cryptic species can not be identified accurately by morphology based taxonomy. So, the use of COI gene as a genetic marker could be a better choice for the morphologically similar species identification. Besides, in recent years, species have been declining rapidly due to overfishing, pollution and other environmental disturbances. Therefore, proper emphasis should be given to conserve these species for a better understanding of the genetic diversity of wild populations.

\section{References}

1. Rawankar SA, Wagh GA, and Wadatkar JS 2015. DNA barcoding and phylogenetic analysis of Tyto alba, Otus bakkamoena and Athene brama from Indian subcontinent. International J.. Zoology and Res. (IJZR). 5: 7-14.

2. Ward RD, R Hanner and PDN Hebert 2009. The campaign to DNA barcode all fishes. FISH_BOL. J. Fish Biol. 74: 329-56. 
3. Begum RA 2010. DNA sequence of half of the complete mitochondrial genome of sessile barnacle Megabalanus volcano containing nine protein coding and 13 TRNA genes. Physiol. Ecol. \& Environ. Sci. 1(1\&2): 57-69.

4. Rahman AKA 2005. Freshwater fishes of Bangladesh, Second Edition. Zoological Society of Bangladesh, Dhaka.

5. Folmer O, M Black, W Hoeh, R Lutz, R Vrijenhoek 1994. DNA primers for amplification of mitochondrial cytochrome c oxidase subunit I from diverse metazoan invertebrates. Mol. Mar. Biol. Biotechnol. 3: 294-299.

6. Ward RD, TS Zemlak, BH Innes, PR Last and PDN Hebert 2005. DNA barcoding Australia's fish species. Philosophical Transactions of the Royal Society B. 360: 1847-1857.

7. Hall TA 1999. BioEdit: A user-friendly biological sequence alignment editor and analysis program for Windows 95 /98 NT. Nucleic Acids Symposium Series 41: 95-98.

8. Heng L, J Ruan and R Durbin 2008. Mapping short DNA sequencing reads and calling variants using mapping quality scores. Genome Research 18: 1851-1858.

9. Thompson JD, DG Higgins and TJ Gibson 1994. CLUSTAL W: improving the sensitivity of progressive multiple sequence alignment through sequence weighting, position-specific gap penalties and weight matrix choice. Nucleic Acids Res. 22(22): 4673-80.

10. Siddiqui KU, MA Islam, SMH Kabir, M Ahmad, ATA Ahmed, AKA Rahman, EU Haque, ZU Ahmed, ZNT Begum, MA Hassan, M Khondker and MM Rahman 2007. Encyclopedia of flora and fauna of Bangladesh. Vol. 23. Freshwater Fishes. Asiatic Society of Bangladesh, Dhaka. 300 pp.

11. Hebert PD, A Cywinska and SL Ball 2003. Biological Identifications through DNA barcodes. Proceedings of the Royal Society of London B: Biological Sciences 270: 313-321.

12. Rajkumar G, PS Bhavan, R Udayasuriyan and C Vadivalagan 2015. Molecular identification of shrimp species, Penaeus semisulcatus, Metapenaeus dobsoni, Metapenaeus brevicornis, Fenneropenaeus indicus, Parapenaeopsis stylifera and Solenocera crassicornis inhabiting in the coromandel coast (Tamil Nadu, India) using MT-COI gene. International Journal of Fisheries and Aquatic Studies 2(4): 96-106.

13. Heidi JR, CO Boateng, N Porcino and DL Adam 2015. A comparison of DNA barcoding markers in West African frogs. African J. Herpetology 64(2): 135-147.

14. Sultana A, RA Begum, H Jahan, MS Alam and RM Shahjahan 2015. Nucleotide Sequence of 16S rRNA gene of Clarias gariepinus and its molecular phylogeny with other catfishes. International Journal of Research in Fisheries and Aquaculture 5(1): 33-40.

15. CheLah EF, A Tsolmon and M Ahamad 2015. Molecular identification of local vertebrate species using cytochrome oxidase subunit I (COI) gene. J. Advances in Biotechnology. 5(1): 570-577. 